\title{
The Issue of Non-formal Adult Education in the Czech Republic
}

\author{
Jan Kalenda \\ ${ }^{1}$ Tomas Bata University in Zlin, Czech Republic \\ Correspondence: Jan Kalenda, Tomas Bata University in Zlin, Czech Republic. E-mail: jjakesova@fhs.utb.cz
}

Received: April 10, 2014 Accepted: August 19, 2014 Online Published: December 30, 2014

doi:10.5539/ass.v11n3p37 URL: http://dx.doi.org/10.5539/ass.v11n3p37

\begin{abstract}
This study deals with the issue of non-formal education in the Czech Republic. In this regard, it focuses on the participation of adults in non-formal education in and outside of a workplace and on the conditioning factors of their participation. For this purpose, the study uses a quantitative research strategy through which the data for the representative sample of adults were collected $(\mathrm{N}=1,022)$. The study found that the participation rate of the adult population in non-formal education in the Czech Republic is $29 \%$, where $33 \%$ of adults do participate in non-formal education in the workplace and only $17 \%$ of adults participate outside of the workplace. The main factors affecting the participation of local inhabitants in education are age and socioeconomic status. The higher the status is, the higher the participation is. The current situation in the Czech Republic differs from other countries because of the comparatively large number of self-employed people in the Czech Republic. On the other hand, it shares with other countries a similar structure of people excluded from educational activities.
\end{abstract}

Keywords: lifelong learning, non-formal education, adult education, Czech Republic, adult learner

\section{Introduction}

The aim of this study is to analyze non-formal adult education in the Czech Republic (herein after CR). Specifically, it focuses on the description of the structure of participants in non-formal education and on the factors which influence their participation. In accordance with the statements of many authors (Coombs, 1968, 1985; Coombs \& Ahmed, 1974, p. 8; Desjardins et al., 2006; Tight, 2002, pp. 69-71) and international documents (European Commission, 2000, p. 8) we consider non-formal education to be a type of organized educational activities which take place outside of the formal education system, they are mostly not certificated and are carried out by employers and/or other organizations or participants.

The issue of non-formal adult education falls under the category of lifelong learning, where it assumes a key role (Aspin \& Chapman, 2000; Edwards, 1997; Field, 2001; Illeris, 2004a; Jarvis, 2004, 2008; Rabušicová \& Rabušic, 2008b; Šimek, 1996). That is because a large portion of continuing education is realized through non-formal education, be it in or outside the workplace. For this reason some authors (Rubenson, 2006, 2011a; Desjardins, 2011) emphasise that the importance of non-formal education has been continually increasing over the last twenty years. This claim is supported by documents of the European Union (European Commission, 2000), as well as by the employers emphasising the development of the workforce by means of education directly in the workplace (Desjardins et al., 2006; Boudard \& Rubenson, 2003). In response to this, some authors (Carré, 2000; Coffield, 1999; Tight, 1998a) write about the pressure that is put on individuals by employers to constantly keep educating themselves and about particular legitimate practices that are used for this purpose.

The beginnings of more intensive research into the issue of adult participation in non-formal education can be dated back to the 1980s, when the first extensive research took place in Great Britain. This issue is, at present, still being researched and it occupies the interest of many researchers (Rubenson, 2011a; Slowey, 2011), government institutions and international organizations (Eurostat, 2013; European Commission, 2002; UNESCO, 2005).

According to Richard Desjardin (2011), the research on the issue of adult education deals with three fundamental questions: What is the scope of adult participation? Who are the participants in adult education? And why do certain groups participate in adult education more than others? We will keep these three questions in mind because their answers represent a necessary presumption for the examination of the issue of non-formal adult education in the $\mathrm{CR}$. 
Trying to answer these questions, the international research projects from the beginning of the 1990s state that about one third of adults did participate in some form of continuing education (Sargant, 1990, p. 69). Then this ratio should increase during the 1990s, peaking at 40\% (Sargant et al., 1997, p. 11) which would represent a marginal difference compared to the 1980s, when research in Great Britain (Charnley et al., 1980, p. 7) stated that the number of adult participants in continuing education was around $16 \%$. At the same time, Beinart and Smith (1998) presented different findings than Sargant and his colleagues. According to them, about three quarters of adults were participating in continuing education. The difference between these two research results is, according to observers (Desjardins et al., 2006, p. 27; Tight, 1998b, p. 113; 2002, p. 23), caused by them having defined the educational activities in a different way. While Sargant and his colleagues were mainly focused on formal and non-formal education, Beinart and Smith also dealt with self-education which greatly increased the overall participation rate of adults.

According to research from the 1980s and the 1990s, the dominant social characteristics of participants were: being an educated male in the middle or upper-middle class and living in a city. On the other hand, not a lot of unqualified and semi-qualified workers, blue-collar workers, unemployed and persons on whom children are dependent (usually a mother on parental leave) participated in that research. The same can be stated about elderly people (people over 50 years of age) and about ethnic minorities (McGivney, 1990, pp. 66-118). All these groups are faced with a wide variety of situational, dispositional and institutional barriers that restrict their participation in continuing education (Cross, 1981, p. 98; cf. Rubenson, 2011b).

If we focus on the main characteristics of the research after 2000, we find that comparative methodology is used more and more and it allows for a comparison of the differences in the rate of adult education between countries and/or areas. More sophisticated research is then focused on defining the relationship between the participation of adults in education and the quality of their life (Desjardins, 2008).

The findings of current research show that the number of participants in formal and non-formal adult education has increased since 2000 (Boudard \& Rubenson, 2003; Slowey, 2011; Eurostat, 2013), and they also confirmed that the number of adult participants greatly varies in different countries, even if the countries have a similar economic rating (Desjardins et al., 2006). This is typical mainly for, what is probably the most detailed international comparative research on adults, the International Adult Literacy Survey (IALS, 2000) which distinguishes:

(1) Countries with a high rate of adults participating in education, reaching over $50 \%$ adults participating in education. Particularly Scandinavian countries belong to this group.

(2) Countries with above-average participation. Mainly Anglo-Saxon and north-western European countries with $35-50 \%$ of adults participating in continuing education belong to this group.

(3) Countries with average participation, i.e. western, middle and south European countries, educating about $20-30 \%$ of adults. For example Italy, France, Czech Republic and Germany are among these countries.

(4) Countries with no more than $20 \%$ of population participating in continuing education. These are south-eastern and eastern European countries, e.g. Greece or Poland.

Despite this difference, most of the countries show a similar pattern of participation in continuing education and this pattern has not changed much since the 1980s and 1990s (Desjardins et al., 2006). To this claim, we will add a statement that even though there is a very similar social structure of groups excluded from education, the rate of exclusion does vary in individual countries. The policy of some countries can, for example, positively affect the inclusion of women and ethnic minorities, and therefore can restrict their exclusion. This leads to a conclusion that one of the main factors that determine the rate of adult participation in education is government policy (Rubenson \& Desjardins, 2009; Jarvis, 2005).

\section{Adult Education in the Czech Republic}

The information on non-formal adult education in the CR were collected from three main sources: (1) annual survey on the adult participation in education carried out by the European Union (Eurostat, 2013); (2) international survey of reading literacy, carried out in the CR in 1997 (IALS, 2000); and (3) the Rabušic research, carried out in 2005 (Rabušicová \& Rabušic, 2008a).

When examining the Eurostat data, it can be stated that since 2002 (when the first research was carried out) the number of people involved in some type of continuing education, including non-formal education, has been steadily increasing. The number had grown from around 5\% to $10-11 \%$ in the last decade. For 2013 it can be stated that adult participation had slightly decreased from $11.1 \%$ to $9.9 \%$ (Eurostat, 2013).

The results of IALS (2000) rank the CR among the countries with an average level of participation. The tangible data state that $26.4 \%$ of adults between $20-65$ years of age did participate in non-formal education. Where $19.8 \%$ 
of adults participated in education that was connected with their work and only up to $7 \%$ did participate in education that was not connected with their work. The structure of participants can be said to be mainly people with higher education who were employed as 'white collars'. On the other hand, participation of manual workers was very low.

The Rabušic research (2008a) was different from these two studies because it also focused on the effects of some sociodemographic factors and it pays more attention to the frequency of educational activities. The authors worked with a representative sample of the Czech population $(\mathrm{N}=1,413)$ and they found that $34 \%$ of adults did participate in non-formal education in 2005. While there were no significant differences found between the number of male and female respondents, the education of respondents was the key factor in their participation. The higher the education of respondents, the more likely they were to participate in education.

The difference in the findings of these three studies was caused by two substantial factors. First, they all differ in terms of the time period about which respondents are asked to report their educational activities. Eurostat sets this time period at one month prior to the survey, the research by Rabušic and IALS sets the time period to one year prior to the survey. This is the reason why Eurostat results show much lower participation than the other two studies. Second, a higher portion of participating adults in the Rabušic research is probably caused by the fact that their research took place 8 years after the IALS research, and the number of Czech adults participating in non-formal education had increased since then.

Although these three studies do take into account the basic characteristics of non-formal adult education in the $\mathrm{CR}$, they also have some drawbacks. Eurostat data offer only general information on the rate of adult participation within a very short time period. IALS data offer more detailed information about non-formal education in the CR, but this data is from 1990s and the research is not concerned with what the conditioning factors are for adult participation in non-formal education. Despite the fact that, in our opinion, the Rabušic research provides the most detailed insight into the issue of non-formal education, there are some methodological procedures that we disagree with. Specifically, it is the usage of seven pre-defined categories of non-formal education, which were offered to respondents as a set of answers and into which the whole of non-formal education was divided. We believe that this limited the range of possible non-formal education activities and therefore distorted the results concerning the participation in educational activities. Last but not least, it is important to note that none of these researches is covering the current state of adult education. It has been 9 years since the latest research.

Also, they do not emphasise the differences between non-formal education in the workplace and outside the workplace which, we believe, plays a more important role than the distinction between the reasons for education (i.e. education for professional growth and/or education for other goals, not connected with professional ones). This is important to note for two reasons: because the annual education of employees is required by law in some professions in the CR and because most of the educational activities do primarily happen in the workplace (Illeris, 2004b; cf. Beinart \& Smith, 1998). Non-formal education that does not happen in the workplace or is not connected with professional goals is much less frequent (Desjardins, 2011b). Moreover, as Courtney (1992, p. 50) points out, determining the difference between education for professional and non-professional goals is very difficult. On these bases we conclude that it is more appropriate to distinguish between education in the workplace (during working hours) and education outside the workplace (in free time).

Therefore, the main goal of this study is to determine the rate of adult participation in non-formal education in the CR. We will distinguish between non-formal education in and outside the workplace. Subsequently, we will determine what social groups are or are not participating in both of these forms of education as well as the sociodemographic factors that condition such participation. Establishing such research goals greatly helps to expand our understanding of adult education because they state: (1) what the changes of non-formal education in the CR since 2005 are; (2) the ratio of adults who participate in non-formal education in the workplace and what the dominant groups are; (3) whether or not sociodemographic characteristics such as sex, age or social status are factors for the participation in non-formal education.

\section{Methodology}

Quantitative research was used for the purpose of this study. This allowed for the collection of data from a representative sample of adults in the CR. Trained interviewers questioned the survey participants, who were older than 18 (i.e. adults) within the quota sampling areas. Basic sociodemographic data were collected in a specific way, so that the final structure of the representative sample would correspond to the population structure of the CR. 
Table 1. Description of participants

\begin{tabular}{|c|c|c|c|}
\hline & & Number $(\mathbf{N})$ & Percentage \\
\hline \multirow{2}{*}{ Gender } & Male & 499 & $48.8 \%$ \\
\hline & Female & 523 & $51.2 \%$ \\
\hline \multirow{6}{*}{ Age } & $18-24$ & 121 & $11.8 \%$ \\
\hline & $25-34$ & 190 & $18.6 \%$ \\
\hline & $35-44$ & 181 & $17.7 \%$ \\
\hline & $45-54$ & 169 & $16.5 \%$ \\
\hline & $55-64$ & 174 & $17 \%$ \\
\hline & $65+$ & 187 & $18.3 \%$ \\
\hline \multirow{10}{*}{ Economic activity } & Self-employed & 56 & $5.5 \%$ \\
\hline & Employed & 537 & $52 \%$ \\
\hline & Unemployed & 62 & $6.1 \%$ \\
\hline & Retired & 259 & $25.3 \%$ \\
\hline & At home & 41 & $4 \%$ \\
\hline & Student & 67 & $6.6 \%$ \\
\hline & Highly qualified employee & 19 & $3.5 \%$ \\
\hline & Senior manager with 6 or more subordinates & 6 & $1.1 \%$ \\
\hline & Senior manager with 5 or less subordinates & 8 & $1.5 \%$ \\
\hline & Manager with 6 or more subordinates & 36 & $6.7 \%$ \\
\hline \multirow[t]{5}{*}{ Socioeconomic status of an employee } & Manager with 5 or less subordinates & 32 & $6 \%$ \\
\hline & Employee doing non-manual work at the office & 162 & $30.2 \%$ \\
\hline & Employee doing non-manual work outside the office & 47 & $8.8 \%$ \\
\hline & Qualified manual worker & 161 & $30.0 \%$ \\
\hline & Unqualified manual worker & 66 & $12.3 \%$ \\
\hline \multirow{4}{*}{ Socioeconomic status of a Self-employed } & Highly qualified person & 9 & $16.1 \%$ \\
\hline & Entrepreneur with 6 or more employees & 5 & $8.9 \%$ \\
\hline & Entrepreneur with 5 or less employees & 38 & $67.9 \%$ \\
\hline & Farmer/Collective farmer & 4 & $7.1 \%$ \\
\hline \multirow{4}{*}{ Size of local population } & up to 2,000 inhabitants & 205 & $20.1 \%$ \\
\hline & up to 20,000 inhabitants & 357 & $34.9 \%$ \\
\hline & up to 100,000 inhabitants & 225 & $22 \%$ \\
\hline & over 100,000 inhabitants & 235 & $23 \%$ \\
\hline
\end{tabular}

Therefore, a structured interview of 15-20 minutes was used as a research technique. The questions of the interview were focused on non-formal adult education. The representative sample data from 1,022 respondents were collected by the method presented above. The structure can be found in Table 1 .

Unlike some of the other research on adult education which usually focuses on adults between 20-65 years old, we also focused on younger (18-19 years) and older (over 65 years) people who are usually excluded from such research (see Eurostat, 2013; IALS, 2000; Rabušicová \& Rabušic, 2008a). It is important to note that people between 18 to 24 years (including a large group of students) were advised that this study deals with non-formal education (instead of formal education which includes higher education).

Because the manner of asking questions about education critically affects the results of adult participation in this activity (Desjardins et al., 2006), it was necessary to consider what steps we took in this case. We used a strategy that focused on asking about participation in non-formal education in and outside the workplace during the last 12 months rather than only during the last one month, as was the case of some short-term research (Eurostat, 2013). We pursued the methodology used in the IALS research. But unlike this research, we did not presented the rate of participation in hours but in the number of workshops and seminars attended. We believe that determining an exact number of hours can be very problematic when considering the past 12 months and can lead to distortion of answers. We also wanted to use this method because it was used by the Rabušic (2008a) research and therefore the results of both studies can be partially compared.

The data obtained were then subjected to statistical analysis using the SPSS programme. In this regard, we implemented both, first-degree as well as second-degree sorting - an analysis by the use of defined adjusted residual. Based on this we determined the importance of dependence between the individual sociodemographic characters and the rate of participation in non-formal education. 


\section{Non-formal Adult Education outside the Workplace}

Based on the survey findings, it can be concluded that the vast majority of adults (83\%) in the CR do not participate in non-formal education in their free time. That means that only about one in six adults participates in this form of education (17\%), where $4.5 \%$ of respondents stated that they participate regularly (more than three times a year), occasional participation (2-3 times a year) was reported by $4.6 \%$ of adults and irregular participation (once a year) was reported by $7 \%$ of adults. Therefore it can be concluded that for adults in the CR participation on workshops and seminars outside the workplace is not a particularly popular way of spending their free time.

Apart from discovering the basic rate of participation in non-formal education outside the workplace, we were also interested in how this participation is conditioned by sociodemographic factors and what their statistical importance is. Table no. 2 presents an overview of the key factors and of the distribution of participation in non-formal adult education between various social groups. We will deal with the most important finding presented in Table 2.

From the point of view of participation in non-formal education, the gender of participants is not an important factor. About an equal number of men and women participate in this education which leads to the conclusion that, in the case of continuing education of men and women in the CR, there is no distinct gender discrimination. This conclusion corresponds with the findings of previous research (Rabušicová \& Rabušic, 2008b, p. 72).

On the other hand, the age of respondents is, in two regards, one of the key differentiating factors. First, people older than 55 years virtually never participate in non-formal adult education. Less than one in ten people of the age cohort of 55 to 64 years is involved in some sort of non-formal educational activity which makes this group of people approaching retirement very vulnerable to changes on the labour market that, according to some authors (Lutz, Sanderson \& Scherbov, 2004), does require a constant development of human capital. This finding is, at the same time, also in contrast to recent gerontagogic literature which emphasises that education is an important factor for the quality of life of elderly people (Cavallini, Pagnin \& Vecchi, 2003; Vives, Orte \& Macías, 2012). The reasons for the low rate of participation of people over 55 years can be found in the inadequate offering of non-formal education for these people and in the fact that the scope for the application of knowledge and skills acquired through non-formal education is very narrow for these people. According to Krampe and McInnes (2007, p. 255), stereotypes about the ability of the elderly to learn can also have a negative effect on this.

Second, the highest rate of free-time participation in non-formal education in be found among middle-aged (35 to 44 years) adults. Within this group, one in four individuals participates in some form of non-formal education in their free time. Nevertheless, the majority state that they participate in education just occasionally $(9.4 \%)$ or irregularly (11.6\%). Very interesting is the fact that the participation rate of this age group is higher than the participation rate of the age cohort of 25 to 34 years, because it would be expected that its participants would continue their education after the transition from formal education into the employment to further increase their employability. Higher participation of young adults (25 to 34 years) is probably limited by the new roles which individuals have to adopt during this period: individuals often marry, start families and enter into employment. Therefore they do not have much spare time to invest into non-formal education as opposed to the age cohort of 35 to 44 years, whose members have already developed their socio-professional roles and started families. Another interesting fact is the relatively low participation rate of the age group of 18 to 24 years. Only $16 \%$ of its members participate in educational activities and further develop their knowledge and skills outside the system of formal education. Therefore, the development of knowledge and skills of a large number of young Czech people lies on the shoulders of universities and higher vocational schools.

If we compare these results with data collected by the Rabušic research (2008b, pp. 68-69) in 2005, we can see that there was a partial change in the age structure of people who participate in non-formal education in the CR. While in 2005 mainly people between 20-29 and 30-39 years participated in non-formal education, in 2013 we can see a decrease of interest in non-formal education among people under 30 years of age and increase of interest among people who are over 30 years old. The reason for this change is probably the fact that after 2000 there was a marginal increase in the number of students of universities up to $50-60 \%$ of the current year population (ČSU, 2013; Koucký, 2009; Prudký, Pabián, \& Šima, 2010) due to which the formal instead of non-formal education became the main form of education of people between 20-30 years of age.

The respondent's field of economic activity is another important factor. In this respect, individuals with the most time outside the workplace, i.e. the unemployed, do not participate more in non-traditional education. It is completely the opposite. Employed people have a much higher participation rate than the unemployed, the 
retired or people at home (e.g. mothers on parental leave). Almost one third of employed adults participate in some form of non-formal education outside their workplace and every one out of ten employees states that they are educating themselves regularly.

Table 2. Non-formal education outside the workplace

\begin{tabular}{|c|c|c|c|c|c|c|c|c|c|}
\hline \multirow[b]{2}{*}{ Factors } & \multirow[b]{2}{*}{ Participation in education } & \multicolumn{2}{|c|}{ Attendance Regular } & \multicolumn{2}{|c|}{ Occasional } & \multicolumn{2}{|c|}{ Irregular } & \multicolumn{2}{|c|}{ Does not attend } \\
\hline & & $\%$ & $\begin{array}{l}\text { Adjusted } \\
\text { residual }\end{array}$ & $\%$ & $\begin{array}{l}\text { Adjusted } \\
\text { residual }\end{array}$ & $\%$ & $\begin{array}{l}\text { Adjusted } \\
\text { residual }\end{array}$ & $\%$ & $\begin{array}{l}\text { Adjusted } \\
\text { residual }\end{array}$ \\
\hline \multirow{2}{*}{ Gender } & Male & 4.6 & 0.2 & 3.4 & -1.4 & 6.8 & -0.7 & 85.2 & 1.2 \\
\hline & Female & 4.4 & -0.2 & 5.2 & 1.4 & 8 & 0.7 & 82.4 & -1.2 \\
\hline \multirow{6}{*}{ Age } & $18-24$ & 3.3 & -0.7 & 6.6 & 1.3 & 6.6 & -0.4 & 83.5 & -0.1 \\
\hline & $25-34$ & 6.3 & 1.3 & 2.6 & -1.3 & 12.1 & $2.7^{*}$ & 78.9 & $-2 *$ \\
\hline & $35-44$ & 5.5 & 0.7 & 9.4 & $3.7 * *$ & 11.6 & $2.4^{*}$ & 73.5 & $-4.1 * * *$ \\
\hline & $45-54$ & 7.1 & 1.8 & 3.6 & -0.5 & 7.1 & -0.2 & 82.2 & -0.6 \\
\hline & $55-64$ & 1.7 & -1.9 & 2.9 & -1 & 4.0 & -1.9 & 91.4 & $3.0 * *$ \\
\hline & $65+$ & 2.7 & -1.3 & 1.6 & $-2^{*}$ & 2.7 & $-2.7^{*}$ & 93 & $3.8^{* *}$ \\
\hline \multirow{5}{*}{$\begin{array}{l}\text { Economic } \\
\text { activity }\end{array}$} & Employed & 10.7 & $2.3^{*}$ & 12.5 & $3.1 * *$ & 7.1 & -0.1 & 69.6 & $-2.9 *$ \\
\hline & Unemployed & 5.6 & 1.8 & 4.8 & 0.9 & 9.7 & $2.9^{*}$ & 79.9 & $3.5^{* *}$ \\
\hline & Retired & 1.2 & $-3 * *$ & 1.5 & $-2.5^{*}$ & 3.1 & $-3.1 * *$ & 94.2 & $5.3 * * *$ \\
\hline & At home & 2.4 & -0.6 & 4.9 & 0.2 & 12.2 & 1.2 & 80.5 & -0.6 \\
\hline & Student & 6 & 0.6 & 6 & 0.7 & 4.5 & -1 & 83.6 & 0 \\
\hline \multirow{9}{*}{$\begin{array}{l}\text { Socioeconomic } \\
\text { status } \\
\text { of employees }\end{array}$} & Highly qualified employee & 21.1 & $3 * *$ & 15.8 & $2.3^{*}$ & 15.8 & 0.9 & 47.4 & $-3.6 * *$ \\
\hline & $\begin{array}{l}\text { Senior manager with } 6 \text { or more } \\
\text { subordinates }\end{array}$ & 0 & -0.6 & 16.7 & 1.4 & 33.3 & $2 *$ & 50 & -1.8 \\
\hline & $\begin{array}{l}\text { Senior manager with } 5 \text { or less } \\
\text { subordinates }\end{array}$ & 12.5 & 0.9 & 0 & -0.6 & 12.5 & 0.3 & 75 & -0.3 \\
\hline & $\begin{array}{l}\text { Manager with } 6 \text { or more } \\
\text { subordinates }\end{array}$ & 16.7 & $3 * *$ & 8.3 & 1 & 13.9 & 0.9 & 61.1 & $-2.9 *$ \\
\hline & $\begin{array}{l}\text { Manager with } 5 \text { or less } \\
\text { subordinates }\end{array}$ & 15.6 & $2.5^{*}$ & 9.4 & 1.2 & 9.4 & -0.1 & 65.6 & $-2.1^{*}$ \\
\hline & $\begin{array}{l}\text { Employee doing non-manual } \\
\text { work at the office }\end{array}$ & 6.2 & 0.4 & 8 & $2.3^{*}$ & 13 & 1.7 & 72.8 & $-2.7^{*}$ \\
\hline & $\begin{array}{l}\text { Employee doing non-manual } \\
\text { work outside the office }\end{array}$ & 2,1 & -1.1 & 2.1 & -0.9 & 10.6 & 0.2 & 85.1 & 0.9 \\
\hline & Qualified manual worker & 0.6 & $-3.3 * *$ & 0.6 & $-3 * *$ & 6.8 & 1.5 & 91.9 & $4.6 * * *$ \\
\hline & Unqualified manual worker & 3 & -1 & 1.5 & -1.3 & 1.5 & $-2.4^{*}$ & 93.9 & $3 * *$ \\
\hline \multirow{4}{*}{$\begin{array}{l}\text { Socioeconomic } \\
\text { status of a } \\
\text { self-employed } \\
\text { person }\end{array}$} & Highly qualified & 22.2 & 1.2 & 11.1 & -0.1 & 11.1 & 0.5 & 55.6 & -1 \\
\hline & $\begin{array}{l}\text { Entrepreneur with } 6 \text { or more } \\
\text { employees }\end{array}$ & 40 & $2.2 *$ & 20 & 0.5 & 0 & -0.6 & 40 & -1.5 \\
\hline & $\begin{array}{l}\text { Entrepreneur with } 5 \text { or less } \\
\text { employees }\end{array}$ & 5.3 & -1.9 & 13.2 & 0.2 & 7.9 & 0.3 & 73.7 & 1 \\
\hline & Farmer & 0 & -0.7 & 0 & -0.8 & 0 & -0.6 & 100 & 1.4 \\
\hline \multirow{4}{*}{$\begin{array}{l}\text { Size of local } \\
\text { population }\end{array}$} & up to 2,000 inhabitants & 3.4 & -0.8 & 2.9 & -1.1 & 8.3 & 0.5 & 85.4 & 0.7 \\
\hline & up to 20,000 inhabitants & 5.3 & 0.9 & 5 & -0.9 & 6.4 & -0.4 & 83.2 & -0.4 \\
\hline & up to 100,000 inhabitants & 5.3 & 1.6 & 6.2 & -0.8 & 6.2 & -0.7 & 82.2 & -0.7 \\
\hline & over 100,000 inhabitants & 3.4 & -1.5 & 2.6 & 1.3 & 9.4 & 0.4 & 84.7 & 0.4 \\
\hline
\end{tabular}

Note. Test of significance: * significant result - adjusted residual $\geq 2$ or $\leq-2 ; * *$ very significant result - adjusted residual $\geq 3$ or $\leq-3 ; * * *$ extremely significant result - adjusted residual $\geq 4$ or $\leq-4$.

A surprising situation can be found among the unemployed, where $80 \%$ of people state that they do not participate in any form of non-formal education. If we add the $12.2 \%$ of unemployed, who irregularly participate in some form of education, we can state that the vast majority of unemployed people in the CR are not trying very hard to participate in any education. Due to this they are not able to develop their knowledge and skills and thus improve their position on the labour market.

The reasons for this may lie in two causes (or possibly in a combination of these): either there is no optimal offer of education possibilities for this social group, or the unemployed are aware that even improvement of their knowledge and skills is not sufficient for the improvement of their position on the labour market. That is why they only rarely participate in any non-formal education.

The third group of key factors is the socioeconomic status of respondents. To determine this, the international classification of Erikson and Goldthorpe (1992) was used. It distinguishes job positions from highly qualified 
and managerial positions, typical for white collar workers, up to non-qualified manual workers, typical for blue collar workers (see Table no.2: The socioeconomic status of employees). As a specific category we distinguish the socioeconomic status of self-employed people which make up about $10 \%$ in the CR and who represent so-called intermediate class positions, i.e. positions between white and blue collars (Katrňák \& Fučík, 2010).

For the socioeconomic status of employees it is true that the higher the status the higher the chance of the individual participating in further education. The group with the highest participation rate are highly qualified workers (e.g. doctors, consultants, architect, etc.) of which more than one half participate in education in their free time. Moreover every fifth person participates in more than three workshops/seminars every year. A similar participation rate can be seen among the high manager positions with 6 or more subordinates. In contrast to the highly qualified workers most of them (about one third) participate irregularly in non-formal education in their free time. This is due to the fact that this group is heavily engaged in non-formal education in the workplace (see below). Beyond these socioeconomic categories, managers also often participate in such education; 35-39\% of them participate in educational activities and $15-16 \%$ state that they participate regularly.

The lowest participation rate in non-formal education can be seen among the manual workers, be it qualified or non-qualified 'blue collar workers'. Only every tenth or eleventh manual worker participates in non-formal education in their free time. This is the reason why there is an exclusion of manual workers from non-formal adult education.

The situation of self-employed people is very specific in the CR. Highly qualified people who are self-employed, and medium and large businesses entrepreneurs (i.e. those who have six or more employees) show a very high participation rate (46-60\% of them participate in some form of education). This high number of participating self-employed people is probably due to the fact that they are forced to develop their knowledge and skills more than people who are employed. On the other hand, the number of participants among small businesses entrepreneurs (i.e. those who have less than six employees) is significantly lower - only $25 \%$ of them states that they participate in workshops and seminars. They are, unlike the medium and large businesses entrepreneurs, probably more busy and do not have as much free time for non-formal education.

The last factor which we tested was the population of the municipality of residence. It does not play any significant role in the participation rate of people in non-formal education in their free time. The presumption that small municipalities do not have a well-developed infrastructure for adult education proved to be unfounded.

\section{Non-formal Adult Education in the Workplace}

The image of non-formal education in the CR would not be complete without insight into what is happening during working hours. In this regard we focused on workshops and seminars that economically active self-employed people underwent in the preceding year other than the BOZP (Workplace Safety) training, which is mandatory for all working people. For this analysis we used a slightly smaller sample $(\mathrm{N}=593)$ than in previous analyses because we excluded students, retired people, unemployed and people at home.

The most significant finding of this part of research is that more adults are participating in non-formal education during their work time rather than in their free time. We identify that $33 \%$ of adults are participating in education during their work time, where $9 \%$ stated that they participate regularly, $10 \%$ participate occasionally and $13 \%$ participate irregularly (no more than once in the last 12 months). Even though these data are higher than in the last case, they show that two thirds of working people in the CR are not participating in education during their work time. Therefore, it is appropriate to ask whether we can consider the companies in the CR to be 'learning organizations' (Senge, 1990).

As with the non-formal education outside the workplace, this form of education is also highly differentiated on the bases of sociodemographic characters. The overview of all key factors and of participation of various social groups is presented in Table 3. From the sociodemographic characters that we analysed, two are the most important - socioeconomic status and age.

With regards to age, the least participating group are employees between 55 and 64 years of age. Almost three quarters state that they do not participate in any education in their workplace. Therefore, employers do not invest into incensement of the qualification or into requalification of employees over 55 years of age, which is the reason why this group is one of the most vulnerable groups on the current labour market (Mareš, 2002).

It is surprising that the second group with the least participation in employee education is the age cohort of 25-34 years. Two thirds state that they do not participate in education and those who attend some workshops or seminars can be divided into two groups - participating regularly $(9.5 \%)$ and participating irregularly $(18 \%)$. The distinction between young employees, who are already highly qualified and into whose education the companies 
are willing to invest, and employees working in non-manual positions at the office or manual workers, for whom there are no preconditions for education in the workplace are being created, does probably play a role in this differentiation.

The exact opposite situation can be found among middle-aged employees (35-44 years) who participate the most in educational activities in the workplace. Almost $40 \%$ are participating in some form of education and one out of ten people states that $\mathrm{s} /$ he is participating regularly.

A factor which has an even greater impact on adult participation in education in the workplace is the socioeconomic status of employees and self-employed persons. The higher the status the higher the chance that individuals will, during their working hours, educate or develop their skills. This is why the highest participation rate can be found among highly qualified workers and senior manages.

In the case of highly qualified workers, almost a quarter is regularly participating in education and a quarter is not participating at all. All senior managers declare an even higher participation rate. Only 14-16\% of them are not participating in any education at all. The difference between senior managers and highly qualified workers is that highly qualified workers do not participate regularly but occasionally. This difference is even more obvious if we look at the differences between senior managers with 6 or more subordinates and those with 5 or less. Those who have a smaller number of workers for whom they are responsible participate more irregularly. This implies that at senior manager positions the overall participation rate and frequency of activities is conditioned by their socioeconomic status.

Table 3. Non-formal education in the workplace $(\mathrm{N}=593)$

\begin{tabular}{|c|c|c|c|c|c|c|c|c|c|}
\hline \multirow[b]{2}{*}{ Factors } & \multirow[b]{2}{*}{ Participation in education } & \multicolumn{2}{|c|}{ Regular } & \multicolumn{2}{|c|}{ Occasional } & \multicolumn{2}{|c|}{ Irregular } & \multicolumn{2}{|c|}{ Does not attend } \\
\hline & & $\%$ & $\begin{array}{l}\text { Adjusted } \\
\text { residual }\end{array}$ & $\%$ & $\begin{array}{l}\text { Adjusted } \\
\text { residual }\end{array}$ & $\%$ & $\begin{array}{l}\text { Adjusted } \\
\text { residual }\end{array}$ & $\%$ & $\begin{array}{l}\text { Adjusted } \\
\text { residual }\end{array}$ \\
\hline \multirow{2}{*}{ Sex } & Male & 8.6 & -0.7 & 9.6 & -0.5 & 14.1 & 0.5 & 67.4 & 0.4 \\
\hline & Female & 10.2 & 0.7 & 10.9 & 0.5 & 13 & -0.5 & 65.9 & -0.4 \\
\hline \multirow{5}{*}{ Age } & $18-24$ & 14 & 1.1 & 11.6 & 0.3 & 9.3 & -0.9 & 65.1 & -0.2 \\
\hline & $25-34$ & 9.5 & 0 & 5.3 & -1.3 & 18.1 & 1.9 & 67.2 & 0.2 \\
\hline & $35-44$ & 10.2 & 0.4 & 14.6 & $2.1^{*}$ & 12.7 & -0.4 & 62.4 & -1.3 \\
\hline & $45-54$ & 7.8 & -0.8 & 10.4 & 0.1 & 15.6 & 0.8 & 66.2 & -0.1 \\
\hline & $55-64$ & 5.8 & -1.2 & 7 & -1.1 & 10.5 & -0.9 & 76.7 & $2.2 *$ \\
\hline \multirow{9}{*}{$\begin{array}{c}\text { Socioeconomic } \\
\text { status of an } \\
\text { employee }\end{array}$} & Highly qualified employee & 26.3 & $2.9^{*}$ & 26.3 & $2.3^{*}$ & 21.1 & 0.9 & 26.3 & $-3.8 * *$ \\
\hline & $\begin{array}{l}\text { Senior manager with } 6 \text { or more } \\
\text { subordinates }\end{array}$ & 16.7 & 0.7 & 33.3 & 1.8 & 33.3 & 1.3 & 16.7 & $-2.6^{*}$ \\
\hline & $\begin{array}{l}\text { Senior manager with } 5 \text { or less } \\
\text { subordinates }\end{array}$ & 14.3 & 0.6 & 14.3 & 0.3 & 57.1 & 3.3 & 14.3 & $-3.0 * *$ \\
\hline & $\begin{array}{l}\text { Manager with } 6 \text { or more } \\
\text { subordinates }\end{array}$ & 19.4 & $2.5^{*}$ & 22.2 & $2.3 *$ & 19.4 & 0.9 & 38.9 & $-3.7 * *$ \\
\hline & $\begin{array}{l}\text { Manager with } 5 \text { or less } \\
\text { subordinates }\end{array}$ & 16.1 & 1.6 & 13.2 & $2.8^{*}$ & 22.6 & 1.4 & 45.2 & $-2.6^{*}$ \\
\hline & $\begin{array}{l}\text { Employee doing non-manual } \\
\text { work at the office }\end{array}$ & 11.2 & 1.3 & 16.2 & $2.8^{*}$ & 11.2 & -1.3 & 61.3 & -1.8 \\
\hline & $\begin{array}{l}\text { Employee doing non-manual } \\
\text { work outside the office }\end{array}$ & 2.2 & -1.6 & 0.0 & $-2.4 *$ & 19.6 & 1.1 & 78.3 & 1.7 \\
\hline & Qualified manual worker & 3.1 & $-2.8^{*}$ & 3.8 & $-3.3 * *$ & 11.9 & -1 & 81.1 & $4.6 * * *$ \\
\hline & Unqualified manual worker & 1.6 & $-2.1 *$ & 4.7 & -1.6 & 7.8 & -1.6 & 85.9 & $3.5^{* *}$ \\
\hline \multirow{4}{*}{$\begin{array}{l}\text { Socioeconomic } \\
\text { status } \\
\text { Self-employed }\end{array}$} & $\begin{array}{l}\text { Highly qualified self-employed } \\
\text { person }\end{array}$ & 22.2 & 0.2 & 11.1 & 0.8 & 33.3 & $2.8^{*}$ & 33.3 & $-2.1^{*}$ \\
\hline & $\begin{array}{l}\text { Entrepreneur with } 6 \text { or more } \\
\text { employees }\end{array}$ & 60 & $2.4^{*}$ & 0.0 & -0.6 & 0.0 & -0.7 & 40 & -1.2 \\
\hline & $\begin{array}{l}\text { Entrepreneur with } 5 \text { or less } \\
\text { employees }\end{array}$ & 15.8 & -1.1 & 7.9 & 0.3 & 5.3 & -1.4 & 71.1 & 1.5 \\
\hline & Farmer/Collective farmer & 0 & -1 & 0 & -0.6 & 0 & -0.6 & 100 & 1.5 \\
\hline \multirow{4}{*}{$\begin{array}{l}\text { Size of local } \\
\text { population }\end{array}$} & up to 2,000 inhabitants & 3.7 & $-2.2 *$ & 6.5 & -1.4 & 18.3 & 1.7 & 71 & 1.1 \\
\hline & up to 20,000 inhabitants & 12.3 & 1.7 & 13.8 & $2 *$ & 9.2 & $-2.2 *$ & 64.6 & -0.7 \\
\hline & up to 100,000 inhabitants & 8.2 & -0.5 & 11.2 & 0.4 & 13.4 & -0.1 & 67.2 & 0.2 \\
\hline & over 100,000 inhabitants & 10.8 & 0.7 & 7.4 & -1.3 & 16.2 & 1 & 65.5 & -0.3 \\
\hline
\end{tabular}

Note1: Test of significance: * significant result - adjusted residual $\geq 2$ or $\leq-2 ; * *$ very significant result - adjusted residual $\geq 3$ or $\leq-3 ; * * *$ extremely significant result - adjusted residual $\geq 4$ or $\leq-4$.

Note 2: only the employees or self-employed were questioned. 
Relatively high participation in educational activities can be seen among middle management of companies, among whom $16-19 \%$ of respondents' state that they participate regularly. But in the case of middle leading positions the participation rate of managers is diminishing. More than one third does not participate in any educational activities in their workplace.

The situation of manual workers, be it qualified or unqualified, is completely different. Blue collar workers do not participate in any education during their work time; $81-85 \%$ of workers state that they do not participate in any type of education in the workplace. The highest adjusted residual from among all observed groups was identified for this group (3.5 and 4.6). This means that the impact of social status is crucial. If there is any participation of manual workers in education, it is always very rare, i.e. no more than once a year. The possible cause for this is the fact that most jobs for qualified and non-qualified workers in the CR do not require a systematic development of knowledge and skills and the fact that most workers do not have a extensive experience with educational activities. According to some authors (Katrňák, 2004; Nedbálková, 2012), education does not represent an important value for them.

The situation with highly qualified self-employed people and of entrepreneurs with more than six employees is also interesting. In both of these social groups we can see high utilization of educational activities in the workplace. Most of the medium and large business entrepreneurs $(60 \%)$ state that they participate in educational activities during their work time. But the situation of small business entrepreneurs is completely different. In their case, only $16 \%$ of individuals participate regularly which is only one quarter the rate of medium and large business entrepreneurs. The number of those, who do not participate in any education, is also significantly higher (71\%). The issue of different participation rates in educational activities that we described in non-formal education outside the workplace can be found here as well.

Last of the tested factors - population of the municipality of residence - showed two interesting results. Despite the fact that there is no linear relation between population of the municipality of residence and a higher participation rate in educational activities, the local population does affect the frequency of adult participation. If people live in a small municipality (up to 2,000 inhabitants) it is very unlikely that they participate regularly in educational activities. And, at the same time, if people live in a small town (2,000 to 20,000 inhabitants), the possibility of them participating in educational activities once a year increases.

\section{Conclusion}

The overall rate of participation in non-formal education in the CR is not very high. Our research shows that $29 \%$ of adults participate in such education, where $17 \%$ of adults participate in their free time and $33 \%$ of adults participate during their work time. We can conclude from the results that the centre of adult education in the CR is the working world. In it, better prerequisites for adult education are created - be it because the employers financially and logistically provide the educational courses or because the employees attend the educational activities during their work time instead of during their free time. Because of these measures, some of the fundamental problems of adult education are taken care of, such as the financial demand or lack of free time.

When comparing the results of this research with international statistics (IALS 2000) on adult participation in non-formal education, we can see that the CR is still among the countries with average participation (20-35\% of adults are participating in non-formal education in these countries). To understand the position of the CR among other countries, it must be stated that that position will depend on which of the presented frequencies will be taken as a starting point for comparison. Using the data on education in the workplace, then the participation rate in the CR approaches the limit denoting countries with high participation. If, on the other hand, the data on education during one's free time is used, then the participation rate in the CR approaches the limit denoting countries with low participation.

Comparison in terms of the time periods is also interesting. Data from 2013 show a slightly lower participation rate in adult education (29\%) than data from 2005 - stating a 34\% participation rate (Rabušicová \& Rabušic, 2008 b, p. 68). According to this data, there has been a slight decrease of in the participation rate connected with organised educational activities during the last 8 years. However we assume that our data are, in this regard, slightly distorted due to the inclusion of the $65+$ age group (18\% of respondents) which is missing in the Rabušic (2008b) research. Since this age cohort shows one of the lowest rates of the participation in education, it is logical that it also decreases the overall participation rate of our sample. Therefore we conclude that the current overall participation rate is very similar to that in 2005 . This means that we can see a medium-term stagnation in the number of participants in continuing education in the CR rather than its decline.

A change can be seen in the frequency of education because the number of adults participating regularly (more than 3 times a year) in education has increased. Data from 2013 showed 12\% of people stated that they are 
participating regularly on such activities as opposed to data from 2005 when only $6 \%$ of individuals stated the same (Rabušicová \& Rabušic, 2008b, p. 64). Therefore the number of adults, who are participating in education in the $\mathrm{CR}$, is more or less the same but the number of those who are participating very often is increasing. Such a development is probably caused by the fact that, in the framework of non-formal education, there are not many new participants but the number of educational activities of those, who participated in non-formal education in the past, is increasing. Some authors (Courtney, 1992; Tight, 1995) tackle this issue and emphasise that previous experience with educational activities is important for further participation therein.

The structure of participants is crucial for our results. This structure is very diverse. One of the main factors for participation in educational activities is socioeconomic status and partially the age of respondents. This is true for both, education in and outside the workplace. Therefore we believe that it is not possible to talk about education of the whole adult population of the CR, but only about education of certain social groups. That is because, on the bases of socioeconomic status and age, groups of elderly people, manual workers and the unemployed are largely excluded from non-formal education. It is, therefore, dominated by highly qualified and leading, middle-aged workers. This also matches the results of an analysis of people participating in continuing education in Great Britain carried out by Veronica McGivney (1990). Our results also match the results of other research, according to which the non-formal education in the CR is dominated by highly qualified and prominent workers (IALS, 2000, Rabušicová \& Rabušic 2008b, p. 69).

One of the specifics of the CR is that primarily self-employed people are participating in non-formal education. These are usually highly qualified people like doctors, consultants, developers and medium and large entrepreneurs. For them, non-formal education (be it in or outside the workplace) is usually an activity that they use to develop their business and leadership skills. Such a high rate of participation is, in our opinion, caused by the fact that self-employed people themselves are responsible for their own education which Results in their attitude towards education being more proactive.

Despite the fact that this study presents a lot of important findings about the current state of non-formal education in the CR, it must be noted that this study does not, in great detail, deal with the length of participation of individuals in educational activities which can greatly influence the overall scope of participation. It does not consider, for example, the differences between three one-day seminars and one three month training course. This issue appears to be particularly urgent when we realize that the number of people who participate regularly is increasing. In the future, it would be appropriate to find out if the increase in the participation rate of adults is expressed only in the frequency of educational activities or even in their duration or if the increase in the number of educational activities does not take place at the expense of their duration.

For a deeper understanding of the current situation of adult education in the CR, it is essential to consider not only these questions, but many others that emerge from our research findings. First, it is necessary to find a more precise answer to the question of what is the cause of the significant participation/exclusion in adult education of some social groups. In this regard, the main obstacles that individual social groups regard as crucial for their participation must be identified. Then, it is essential to focus on the significance which individual social groups assign to non-formal education, because these enter into the evaluation of education as useful or useless activity (or valuable or worthless experience). We are convinced that if, in future research, there will be an emphasis on these issues, we will be able to better comprehend and describe other aspects of lifelong learning in the CR, which will lead to a better understanding of macro-social and micro-social dimension of non-formal adult education.

\section{Acknowledgments}

This paper was created in collaboration with Focus Agency.

\section{References}

Aspin, D., \& Chapman, J. (2000). Lifelong Learning: concepts and conseptions. International Journal of Lifelong Education, 19(1), 2-19.

Beinart, S., \& Smith, P. (1998). The National Learning Survey, 1997. London: Department for Education and Science.

Bourdard, E., \& Rubenson, K. (2003). Revisiting major determinants of participation in adult education with a direct measure of literacy skills. International Journal of Educational Research, 39(3), 265-280.

Carré, P. (2000). Motivation in Adult Education: From Engagement to Performance. Proceedings of the 41st Annual Adult Education Conference. Vancouver. 
Cavallini, E., Pagnin, A., \& Vecchi, T. (2003). Ageing and everyday memory: the beneficial effect of memory training. Archives of Gerontology and Geriatrics, 37(3), 241-257.

Chranley, A., et al. (1980). Review of Existing Research in Adult and Continuing Education: Vol. 1. - Mature Students. Leicester: NIACE.

Coffield, F. (1999). Breaking the Consensus: lifelong learning as social control. British Educational Research Journal, 25(4), 479-499.

Coombs, P. (1968). The World Education Crisis: A systems analysis. Oxford: Oxford University Press.

Coombs, P. (1985). The World Crisis in Education: the view from the eighties. Oxford: Oxford University Press.

Coombs, P., \& Ahmed, M. (1974). Attacking Rural Poverty: How non-formal education can help. Baltimore: John Hopkins University Press.

Courtney, S. (1992). Why Adults Learn: towards a theory of participation in adult education. London: Routledge.

Cross, K. P. (1981). Adults as Learners. San Francisco: Jossey Bass.

ČSU. (2013). Česká republika od roku 1989 v číslech. Vzdělávání a kultura. Praha: Český statistický úřad.

Desjardins, R. (2008). Researching the Links between and wellbeing. European Journal of Education, 43(1), 23-36.

Desjardins, R. (2011). Participation in AdultLearning. In K. Rubenson (Ed.), Adult learning and Education (pp 205-215). New York, Toronto: Elsevir, Academic Press.

Desjardins, R., et al. (2006). Unequal chances to participate in adult learning: international perspectives. Paris: UNESCO: Internatioanl Institute for Educational Planning.

Edwards, P. (1997). Changing Places? Flexibility, Lifelong learning and Learning Society. London: Routledge.

Erikson, R., \& Goldthorpe, J. H. (1992). The Gustant Flux. A Study of Class Mobility in Industrial Societies. Oxford: Clarendon Press.

European Commission (2000). A Memorandum on Lifelong Learning. Brussel: European Commission.

European Commission. (2002). European Report on Quality Indicators of Lifelong Learning. Brussel: European Commission.

EUROSTAT. (2013). Lifelong learning. Retrieved from http://epp.eurostat.ec.europa.eu/tgm/table.do?tab=table\& init $=1 \&$ language $=$ en \&pcode $=$ tsdsc $440 \&$ plugin $=1$.

Field, J. (2001). Lifelong education. International Journal of Lifelong Education, 20(1-2), 3-15.

IALS. (2000). Literacy in the information Age. Final Report of the International Adult Literacy Survey. Paris: OECD Publishing:

Illeris, K. (2004a). Adult education and adult learning. Copenhagen: Roksilde University Press.

Illeris, K. (2004b). Learning in working life. Copenhagen: Roksilde University Press.

Jarvis, P. (2004). Adult Education and Lifelong Learning. Theory and Practice. London: Routledge.

Jarvis, P. (2005). Adult Education and the State. Towards a politics of adult education. London: Routledge.

Jarvis. P. (2008). Democracy, Lifelong Learning and Learning Society. Active citizenship in a late modern age. London: Routledge.

Katrňák, T. (2004). Odsouzeni k manuální práci. Praha: SLON.

Katrňák, T., \& Fučík, P. (2010). Návrat k sociálnímu původu: Vývoj sociálni stratifikace české společnosti $v$ letech 1989 až 2009. Brno: Centrum pro studium demokracie a kultury.

Koucký, J. (2009). Kolik máme vysokoškoláků? Expanze terciárního vzdělávání v ČR ve vývojovém a srovnávacím pohledu. Aula, 17(1), 5-19.

Krampe, R., \& McInnes, L. (2007). Competence and cognition. In J. Bond, S. Peace, F. Dittmann-Kohli, \& G. Westerhof (Eds.), Ageing in Society. European Perspectives on Gerontology (pp. 255-257). London: Sage Publication.

Lutz, W., Sanderson, W. C., \& Scherbov, S. (Eds.). (2004). The End of World Population Growth in the 21st Century. New Challenges for Human Capital Formation \& Sustainable Development. London: Eartscan. 
Mareš, P. (2002). Nezaměstnanost jako sociálni problém. Praha: SLON.

McGivney, V. (1990). Acces to Education for Non-Participant Adults. Leicester: NIACE.

Nedbálková, K. (2012). Tak daleko, tak blízko: Dělnická třída v České republice. Sociální studia, 9(3), 85-100.

Prudký, L., Pabián, P., \& Šíma, K. (2010). České vysoké školství na cestě od elitního k univerzálnímu vzdělávání 1989 - 2009. Praha: Grada Publishing.

Rabušicová, M., \& Rabušic, L. (Eds.). (2008). Učime se po celý život? O vzdělávání dospělých v České republice. Brno: Masarykova univerzita.

Rubenson, K. (2006). The Nordic model of Lifelong Learning. Compare, 36(3), 327-341.

Rubenson, K. (2011). Barriers to Participation in Adult Education. In K. Rubenson (Ed.), Adult learning and Education (pp. 216-224). New York, Toronto: Elsevir, Academic Press.

Rubenson, K., \& Desjardins, R. (2009). The Impact of Walfare State Requierements on Barriers to Particiaption in Adult Education. A Bounded agency model. Adult Education Qaurterly, 59(3), 187-207.

Sargant, N. (1990). Learning and Leisure. Leicester: NIACE.

Sargant, N., et al. (1997). The Learning Divide. Leicester: NIACE.

Senge, P. M. (1990). The Fifth Discipline: The Art and Practice of the Learning Organization. Doubleday, New York.

Šimek, D. (1996). Andragogika. Olomouc: UP Olomouc.

Slowey, M. (2011). University Adult Continuing Education: The Extra-Mural Tradition Revisited. In K. Rubenson (Ed.), Adult learning and Education (pp. 125-132). New York, Toronto: Elsevir, Academic Press.

Tight, M. (1995). Education, work and adult life: A literature review. Research Papers in Education, 10(3), 381-398.

Tight, M. (1998a). Lifelong learning: oportunity or compusion. British Journal of Educational Studies, 46(3), 251-263.

Tight, M. (1998b). Bridging the learning divide: The nature and politics of participation. Studies in the Education of Adults, 30(2), 110-119.

Tight, M. (2002). Key Concepts in Adult Education and Traning. London, New York: Routledge.

UNESCO. (2005). Towards Knowledge Societies. Paris: UNESCO.

Vives, M., Orte, C., \& Macías, L. (2012). Quality of life, education and seniors. Procedia - Social and Behavioral Sciences, 46, 4598-4602. http://dx.doi.org/10.1016/j.sbspro.2012.06.303.

\section{Copyrights}

Copyright for this article is retained by the author(s), with first publication rights granted to the journal.

This is an open-access article distributed under the terms and conditions of the Creative Commons Attribution license (http://creativecommons.org/licenses/by/3.0/). 